
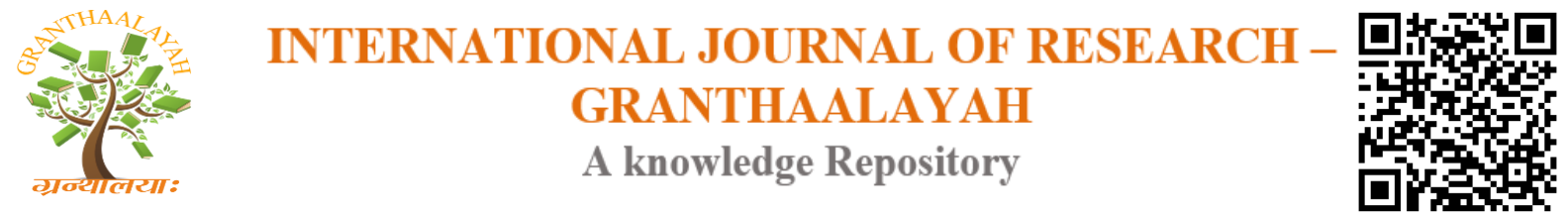

Management

\title{
AWARENESS AND USE OF E-RESOURCES IN DELHI UNIVERSITY, JAMIA MILLIA ISLAMIA AND JAWAHARLAL NEHRU UNIVERSITY: A COMPARATIVE STUDY
}

\author{
Dr. Javed Khan *1 \\ ${ }^{*}$ Assistant Professor, Swami Vivekanand Subharti University, Meerut, INDIA
}

DOI: https://doi.org/10.29121/granthaalayah.v4.i9.2016.2537

\section{ABSTRACT}

User awareness simply means to educate the user. Readers are not aware with the library procedures systems and collection. The topic of present study is "Awareness and use of EResources in Delhi university, Jamia Millia Islamia and jawaharlal Nehru: A comparative study" the main objective of the study is to find out the awareness and use of E-resources among the users of sample of selected universities and also provide the basic information about information sources and resources and how to exploit such resources effectively and efficiently. Through purposive sampling about 200 users from each university were selected for the proposed study. Sample of 600 users from Delhi University, Jamia Millia Islamia, and Jawaharlal Nehru University. The questionnaire was developed was researcher and used as a tool of data collection. Data was analyzed through percentage method. The main finding of the study is that it was found that UG \& PG students of JMI, JNU and DU are 100\% aware about the book service available in the library.

Keywords:

E-Resources, Library, Delhi University, Book Service.

Cite This Article: Dr. Javed Khan, “AWARENESS AND USE OF E-RESOURCES IN DELHI UNIVERSITY, JAMIA MILLIA ISLAMIA AND JAWAHARLAL NEHRU UNIVERSITY: A COMPARATIVE STUDY” International Journal of Research - Granthaalayah, Vol. 4, No. 9 (2016): 68-76.

\section{INTRODUCTION}

Awareness has been known by many different names: library literacy, library orientation, bibliographic instruction, user education, information skills training and information literacy. The user awareness meant for fresher as well as existing and potential users of the library. User awareness simply means to educate the user. Readers are not aware with the library procedures systems and collection. It is an introduction given to reader to help them to make the best use of library. Modern library considered a service institution its aim is to make most effective use of the resources and services by the user's documents are the artificial entities. The awareness of 
documents does not come automatically but when a user comes for the first time in the library. He does not know about catalogue bibliographies, reading lists ad location of the books, and how to access data. Thus, we need a program in which we can explain the user of library tools and system adopted by the library. Such programs are arrangement keeping in view the points of user's informational needs so that he may be able to know their requirements, and them, to use the library effectively and efficiently. The user's awareness includes efforts or programs to guide and instruct the existing and potential users in the use of library service. User's awareness the users are trained in the use of library so that he could reach the documents of his/her interest without anybody help. In India user's awareness have been started workshops and seminars on user awareness through the efforts made by INSDOC, DRTC, IASLIC, UGC and many other organizations.

\subsection{OBJECTIVES OF USER AWARENESS}

- To introduce students to facilities and resources in the library.

- To explain the existing library services and their importance.

- To develop library skills.

- To make students independent users and learners in the library.

- To develop capabilities as self-sufficient users.

- To establish the library as the center of academic activity.

- To provide basic understanding of the library so that users can make efficient use of library materials and services.

- To educate users about information sources and resources and how to exploit such resources effectively and efficiently.

\subsubsection{IMPORTANCE OF USER AWARENESS}

Introducing the uses to the information resources and demonstrating how to make use of the resources is much better than giving the Handbooks, Library guides, leaflets etc. The satisfaction of the readers depends more on the active assistance rendered to him and showing him the availability of the information resources than just indicating through the printed media. It is likely that a reader in spite of efficient and effective devices offered to him may not be able to get the information he wants, more often he faces frustration and disappointment for not properly linked to the resource. It is here the user awareness comes into picture. Through user education programmer a situation is created where in the user is made to accept the library as a partner in his progress and is initiated to appeal for assistant whenever he feels problem of using the library and information resources.

\subsubsection{USER AWARENESS IN UNIVERSITY LIBRARIES}

Universities offer facilities for organized research in all subject fields i.e. Science, Technology, Social Science, Humanities, Medical and Engineering etc. The research is these universities is sponsored by several institutions, like state/central Government, autonomous bodies, Government undertaking and private organizations, etc. These corporate bodes sponsor the research by providing the financial aid for setting up of elaborates, equipment, material required, travel, stipend, scholarships to the scholars. 
Safahieh and Asemi (2008). Studied on "Computer literacy skill of librarians: A case study of Isfahan university libraries, Iran" The factors studied also include Librarians ${ }^{\text {ee }}$ computer use experience, extent of computer literacy, software used, purpose of computer use in their day to day work, benefits derived from computer usage and problems faced in effective use of computer. A questionnaire survey of 73 librarians (41 returned)was used to collect data on computing skills of librarians and their use of Microsoft word, excel, access, power point, library software etc. Data analysis reveals that a majority of the respondents considered their level of computing skills as fair. Sampath Kumar and Biradar (2010) investigated on "Awareness and Use of Library Facilities and Services by the Research Scholars in the Universities in Karnataka: An Analytical Study" Study brought forward significant differences in the satisfaction level of research scholars of different disciplines with facilities and services of libraries. Majority of the respondents of humanities and social science found the facilities and services of university libraries poor, whereas the respondents of science group considered the facilities and services as moderately good.

\section{OBJECTIVES OF THE STUDY}

1) To find out the users awareness about existing library services.

2) To know about the view of the users regarding the internet training programme.

3) To know about the users satisfaction related to services provided by the library.

4) To know about the views of the users regarding the orientation programmes in the library.

5) To find out the problems faced by the users while using library based services.

\section{THE SAMPLE}

A researcher actually wants to study the whole population which is not possible, so the sample is necessary. Contrary to popular opinion, samples are not selected haphazardly. Rather they are chosen in a systematically random way so that chance or the operation of chance or the operation of probability is utilized. The whole population which comprises of users of Delhi University, JamiaMilliaIslamia, and Jawaharlal Nehru University. According to purosive sampling about 200 users from each university were selected for the proposed study.

Sample of 600 users from Delhi University, JamiaMilliaIslamia, and Jawaharlal Nehru University. This sample is based on purposive sampling method.

Awareness about the types of services available in the library

\begin{tabular}{|c|c|c|c|c|c|c|c|c|c|c|c|c|c|}
\hline \multirow[b]{2}{*}{$\begin{array}{l}\text { S.N } \\
0\end{array}$} & \multirow[b]{2}{*}{ variables } & \multicolumn{4}{|c|}{ (JMI) } & \multicolumn{4}{|c|}{$(\mathrm{JNU})$} & \multicolumn{4}{|c|}{$(\mathrm{DU})$} \\
\hline & & $\begin{array}{l}\mathrm{UG} \\
\mathrm{N}=7 \\
3\end{array}$ & $\%$ & $\begin{array}{l}P G \\
N=7 \\
9\end{array}$ & $\%$ & $\begin{array}{l}\mathrm{UG} \\
\mathrm{N}=6 \\
7\end{array}$ & $\%$ & $\begin{array}{l}\mathrm{PG} \\
\mathrm{N}=8 \\
2\end{array}$ & $\%$ & $\begin{array}{l}\mathrm{UG} \\
\mathrm{N}=7 \\
6\end{array}$ & $\%$ & $\begin{array}{l}\mathrm{PG} \\
\mathrm{N}=8 \\
7\end{array}$ & $\%$ \\
\hline $\mathrm{A}$ & Journal & 23 & $\begin{array}{l}31 . \\
5\end{array}$ & 57 & $\begin{array}{l}72 . \\
1\end{array}$ & 32 & $\begin{array}{l}47 . \\
7\end{array}$ & 51 & $\begin{array}{l}62 . \\
1\end{array}$ & 51 & $\begin{array}{l}67 . \\
1\end{array}$ & 63 & $\begin{array}{l}72 . \\
4\end{array}$ \\
\hline B & Book & 73 & 100 & 79 & 100 & 67 & 100 & 82 & 100 & 76 & 100 & 87 & 100 \\
\hline $\mathrm{C}$ & Abstractin & 4 & 5.4 & 7 & 8.8 & 2 & 2.9 & 2 & 2.4 & 3 & 3.9 & 7 & 8 \\
\hline
\end{tabular}




\begin{tabular}{|c|c|c|c|c|c|c|c|c|c|c|c|c|c|}
\hline & $\mathrm{g}$ & & & & & & & & & & & & \\
\hline D & ILL & 13 & $\begin{array}{l}17 . \\
8\end{array}$ & 39 & $\begin{array}{l}49 . \\
3\end{array}$ & 16 & $\begin{array}{l}23 . \\
8\end{array}$ & 27 & $\begin{array}{l}32 . \\
9\end{array}$ & 28 & $\begin{array}{l}36 . \\
8\end{array}$ & 39 & $\begin{array}{l}44 . \\
8\end{array}$ \\
\hline $\mathrm{E}$ & $\begin{array}{l}\text { Reference } \\
\text { Service }\end{array}$ & 37 & $\begin{array}{l}50 . \\
6\end{array}$ & 22 & $\begin{array}{l}27 . \\
8\end{array}$ & 17 & $\begin{array}{l}25 . \\
3\end{array}$ & 13 & $\begin{array}{l}15 . \\
8\end{array}$ & 25 & $\begin{array}{l}32 . \\
8\end{array}$ & 37 & $\begin{array}{l}42 . \\
5\end{array}$ \\
\hline $\mathrm{F}$ & $\begin{array}{l}\text { Bibliograp } \\
\text { hy }\end{array}$ & 10 & $\begin{array}{l}13 . \\
6\end{array}$ & 14 & $\begin{array}{l}17 . \\
7\end{array}$ & 11 & $\begin{array}{l}16 . \\
4\end{array}$ & 10 & $\begin{array}{l}12 . \\
1\end{array}$ & 5 & 6.5 & 14 & 16 \\
\hline $\mathrm{G}$ & $\begin{array}{l}\text { Internet } \\
\text { Section }\end{array}$ & 29 & $\begin{array}{l}39 . \\
7\end{array}$ & 37 & $\begin{array}{l}46 . \\
8\end{array}$ & 33 & $\begin{array}{l}49 . \\
2\end{array}$ & 39 & $\begin{array}{l}47 . \\
5\end{array}$ & 28 & $\begin{array}{l}36 . \\
8\end{array}$ & 47 & 54 \\
\hline $\mathrm{H}$ & CD-ROM & 7 & 9.5 & 3 & 3.7 & 5 & 7.4 & 4 & 4.8 & 3 & 3.9 & 9 & $\begin{array}{l}10 . \\
3\end{array}$ \\
\hline I & Microfish & 2 & 2.7 & 4 & 5 & 2 & 2.9 & 1 & 1.2 & 2 & 2.6 & 4 & 4.5 \\
\hline
\end{tabular}

Table 4.29 indicated that, UG 23 (31.5\%), PG (57 (72.1\%) students of JMI, UG 32(47.7\%) PG $51(62.1 \%)$ students from JNU and UG 51(67.1\%), PG 63(72.4\%), students of DU are aware about journal service available in the library. $100 \%$ students from JMI, JNU and DU are aware about the book service available in the library UG 4(5.4\%), PG 7 (8.8\%) students from JMI, UG 2 (2.9\%) PG 2 (2.4\%) students of JNU and UG 3 (3.9\%), PG 7 (8\%) students of DU are aware about the abstracting and indexing services available in the library.

Those students who are aware about inter library loan service available in the library are UG 13 (17.8\%) PG 39 (49.3\%) students of JMI, UG 16(23.8\%), PG 27 (32.9\%) students of JNU and UG 28 (36.8\%), PG 39 (44.8\%) students of DU. UG 37(50.6\%), PG 22 (27.8\%) students from JMI, UG 17 (25.3\%), PG 13 (15.8\%) from JNU and UG 25 (32.8\%) PG 37 (42.5\%) students of DU are aware about the reference and information service available in the library.

Students who are aware about the bibliography service available in the library in the library are UG 10(13.6\%), PG 14 (17.7\%) students of JMI, UG 11 (16.4\%), PG 10 (12.1\%) students from JNU and UG 5(6.5\%), PG 14 (16\%) students from DU. UG 29 (39.7\%), PG 37 (46.8\%) students of JMI, UG 33 (49.2\%), PG 39 (47.5\%) students from JNU and UG 28 (36.8\%) PG 47(54\%) students of DU are aware about the internet service available in the library.

Students who are aware about CD-ROM service available in the library are UG 7 (9.5\%), PG $3(3.7 \%)$, students from JMI, UG 5 (7.4\%), PG (4.8\%) students of JNU and UG 3 (3.9\%), PG $9(10.3 \%)$ students from DU. UG 2 (2.7\%), PG 4(5\%) students of JMI UG 2(2.9\%), PG 1 (1.2\%) from JNU, UG 2(2.6\%), PG 4(4.5\%) from DU aware about microfilm service available in the library. From the table clearly indicate that $100 \%$ UG and PG students of JMI, JNU and DU are very well aware about book service available in the library.

Problems faced while using E-Resources

\begin{tabular}{|c|c|c|c|c|c|c|c|c|c|c|c|c|c|}
\hline \multirow[b]{3}{*}{ S.N } & \multirow[b]{3}{*}{ variables } & \multicolumn{4}{|c|}{ (JMI) } & \multicolumn{4}{|c|}{ (JNU) } & \multicolumn{4}{|l|}{ (DU) } \\
\hline & & UG & $\%$ & PG & $\%$ & UG & $\%$ & PG & $\%$ & $\mathrm{UG}$ & $\%$ & PG & $\%$ \\
\hline & & $\mathrm{N}=7$ & & $\mathrm{~N}=7$ & & $\mathrm{~N}=6$ & & $\mathrm{~N}=8$ & & $\mathrm{~N}=7$ & & $\mathrm{~N}=8$ & \\
\hline $\mathbf{0}$ & & 3 & & 9 & & 7 & & 2 & & 6 & & 7 & \\
\hline $\mathbf{A}$ & Lack & 33 & 45. & 39 & 49. & 45 & 67. & 36 & 43. & 26 & 34. & 29 & 33. \\
\hline
\end{tabular}




\begin{tabular}{llllllllllllll}
\hline & tanning & & 2 & & 3 & & 1 & & 9 & & 2 & & 3 \\
B & $\begin{array}{l}\text { Internet } \\
\text { Access }\end{array}$ & 19 & 26 & 13 & 16. & 15 & 22. & 29 & 35. & 23 & 30. & 15 & 17. \\
C & $\begin{array}{l}\text { Insufficie } \\
\text { nt }\end{array}$ & 6 & 8.2 & 3 & 3.7 & 2 & 2.9 & 1 & 1.2 & 2 & 2.6 & 4 & 4.5 \\
& & 1 & & & & & & & & & & \\
D & $\begin{array}{l}\text { Generatio } \\
\text { n Gap }\end{array}$ & 2 & 2.7 & 5 & 6.3 & 3 & 4.4 & 3 & 3.6 & 3 & 3.9 & 1 & 1.1 \\
E & $\begin{array}{l}\text { Non- } \\
\text { Cooperati } \\
\text { on }\end{array}$ & 9 & 12. & 11 & 13. & 16 & 23. & 4 & 4.8 & 14 & 18. & 12 & 13. \\
& & & & 9 & & 8 & & & & 4 & & 7 \\
\hline
\end{tabular}

Table 4.17 showed that, UG 33 (45.2\%), PG 39 (49.3\%) students from JMI. UG 45 (67.1\%), PG $36(43.9 \%)$ from JNU and from DU, UG26 (34.2\%), PG 29 (33.3\%) are facing problem while using E- resources due to lack of training. Those students who are facing problem while using $\mathrm{E}$ recourses due internet access are UG 19 (26\%), PG 13(16.4\%) students of JMI. UG 15 (22.3\%), PG 29 (35.3\%) from JNU and UG 23 (30.2\%), PG 15 (17.2\%).UG 6 (8.21\%), PG 3 (3.7\%) students from JMI. UG 2 (2.9\%), PG 1 (1.2\%) from JNU and from DU, UG2 (2.6\%), PG 4 $(4.5 \%)$ are facing problem while using E- recourses due to Insufficient lack of computer training.

Some student are facing problem while using E resources due to generation of re- documentation of information are UG 2(2.7\%), PG 5(6.3\%) of JMI. UG 3(4.4\%), PG 3(3.6\%), of JNU.UG 3(3.9\%), PG 1(1.1\%).UG 9(12.3\%), PG 11(13.9\%) students of JMI. UG 16 (23.8\%), PG 4 (4.8\%) student of JNU and UG 14 (18.4\%), PG 12(13.7\%) from DU are facing problem while using E- resources due to Non-co-operation attitude of staff. From the above table it was concluded that majority of the UG \& PG students from JMI ,JNU, DU are facing problem while using E- resources due to lack of training.

Awareness of internet among users

\begin{tabular}{|c|c|c|c|c|c|c|c|c|c|c|c|c|c|}
\hline \multirow[b]{2}{*}{$\begin{array}{l}\text { S.N } \\
0\end{array}$} & \multirow[b]{2}{*}{ variables } & \multicolumn{4}{|c|}{ (JMI) } & \multicolumn{4}{|c|}{ (JNU) } & \multicolumn{4}{|c|}{ (DU) } \\
\hline & & $\begin{array}{l}\text { UG } \\
\mathrm{N}=7 \\
3\end{array}$ & $\%$ & $\begin{array}{l}\mathrm{PG} \\
\mathrm{N}=7 \\
9\end{array}$ & $\%$ & $\begin{array}{l}\mathrm{UG} \\
\mathrm{N}=6 \\
7\end{array}$ & $\%$ & $\begin{array}{l}\mathrm{PG} \\
\mathrm{N}=8 \\
2\end{array}$ & $\%$ & $\begin{array}{l}\mathrm{UG} \\
\mathrm{N}=7 \\
6\end{array}$ & $\%$ & $\begin{array}{l}\mathrm{PG} \\
\mathrm{N}=8 \\
7\end{array}$ & $\%$ \\
\hline $\mathrm{A}$ & Aware & 39 & $\begin{array}{l}53 . \\
4\end{array}$ & 54 & $\begin{array}{l}68 . \\
3\end{array}$ & 38 & $\begin{array}{l}56 . \\
7\end{array}$ & 36 & $\begin{array}{l}43 . \\
9\end{array}$ & 45 & $\begin{array}{l}59 . \\
2\end{array}$ & 42 & $\begin{array}{l}48 . \\
2\end{array}$ \\
\hline B & $\begin{array}{l}\text { Not } \\
\text { Aware }\end{array}$ & 19 & 26 & 9 & $\begin{array}{l}11 . \\
3\end{array}$ & 24 & $\begin{array}{l}35 . \\
8\end{array}$ & 26 & $\begin{array}{l}31 . \\
7\end{array}$ & 16 & 21 & 19 & $\begin{array}{l}21 . \\
8\end{array}$ \\
\hline $\mathrm{C}$ & $\begin{array}{l}\text { Undivide } \\
\mathrm{d}\end{array}$ & 7 & 9.5 & 4 & 5 & 12 & $\begin{array}{l}17 . \\
9\end{array}$ & 15 & $\begin{array}{l}18 . \\
2\end{array}$ & 6 & 7.8 & 9 & $\begin{array}{l}10 . \\
3\end{array}$ \\
\hline
\end{tabular}

(Multiple answer were permitted)

Table 4.15 indicated the awareness about internet responses. It shows that, the U.G 39(53.4\%), PG 54(68.3\%) from JMI. The UG 38(56.7\%), PG 36(43.9\%) from JNU and from DU, UG 45(59.2\%), and PG $42(48.2 \%)$ are aware about the internet responses. Those who are not aware about the internet response are, UG 19 (26\%), PG 9 (11.3\%) from JMI. The UG 24(35.8\%), PG $26(31.7 \%)$ from JNU and from DU, UG 16(21\%), PG 19 (21.8). The UG 7(9.5\%), PG 4 (5\%) from JMI. The UG 12(17.9), PG 15(18.2\%) from JNU and from DU, UG 6 (7.8\%), PG 9 
(10.3\%) are undivided. From the above tale it was concluded that mostly the UG and PG students from JMI, JNU, and DU are aware about the internet responses.

Use electronic information sources

\begin{tabular}{|c|c|c|c|c|c|c|c|c|c|c|c|c|c|}
\hline \multirow[b]{2}{*}{$\begin{array}{l}\text { S.N } \\
\text { o }\end{array}$} & \multirow[b]{2}{*}{$\begin{array}{l}\text { variable } \\
\text { s }\end{array}$} & \multicolumn{4}{|l|}{ (JMI) } & \multicolumn{4}{|c|}{ (JNU) } & \multicolumn{4}{|l|}{ (DU) } \\
\hline & & $\begin{array}{l}\mathrm{UG} \\
\mathrm{N}=7 \\
3\end{array}$ & $\%$ & $\begin{array}{l}\mathrm{PG} \\
\mathrm{N}=7 \\
9\end{array}$ & $\%$ & $\begin{array}{l}\mathrm{UG} \\
\mathrm{N}=6 \\
7\end{array}$ & $\%$ & $\begin{array}{l}\mathrm{PG} \\
\mathrm{N}=8 \\
2\end{array}$ & $\%$ & $\begin{array}{l}\mathrm{UG} \\
\mathrm{N}=7 \\
6\end{array}$ & $\%$ & $\begin{array}{l}\mathrm{PG} \\
\mathrm{N}=8 \\
7\end{array}$ & $\%$ \\
\hline A & Internet & 23 & $\begin{array}{l}31 . \\
5\end{array}$ & 27 & $\begin{array}{l}34 . \\
1\end{array}$ & 16 & $\begin{array}{l}23 . \\
8\end{array}$ & 26 & $\begin{array}{l}31 . \\
7\end{array}$ & 20 & $\begin{array}{l}26 . \\
3\end{array}$ & 16 & $\begin{array}{l}18 . \\
3\end{array}$ \\
\hline B & E-Mail & 8 & $\begin{array}{l}10 . \\
9\end{array}$ & 2 & 2.5 & 1 & 1.4 & 0 & 0 & 0 & 0 & 0 & 0 \\
\hline $\mathrm{C}$ & E-Journal & 12 & $\begin{array}{l}16 . \\
4\end{array}$ & 24 & $\begin{array}{l}30 . \\
3\end{array}$ & 8 & $\begin{array}{l}11 . \\
9\end{array}$ & 24 & $\begin{array}{l}29 . \\
2\end{array}$ & 29 & $\begin{array}{l}38 . \\
1\end{array}$ & 36 & $\begin{array}{l}41 . \\
3\end{array}$ \\
\hline D & $\begin{array}{l}\text { Online } \\
\text { Date }\end{array}$ & 7 & 9.5 & 6 & 7.5 & 6 & 8.9 & 13 & $\begin{array}{l}15 . \\
8\end{array}$ & 3 & 3.9 & 28 & $\begin{array}{l}32 . \\
1\end{array}$ \\
\hline $\mathrm{E}$ & E-Books & 37 & 50 & 28 & $\begin{array}{l}35 . \\
4\end{array}$ & 39 & $\begin{array}{l}58 . \\
2 \\
\end{array}$ & 30 & $\begin{array}{l}36 . \\
5\end{array}$ & 35 & 46 & 24 & $\begin{array}{l}27 . \\
5\end{array}$ \\
\hline
\end{tabular}

(Multiple answer were permitted)

Table 4.11 shows that the U.G. 23(31.5\%), P.G. 27(34.1\%) from JMI. The U.G. 16(23.8\%). P.G. 26(31.7\%) from JNU and from D.U., UG 20(26.3\%), PG 16(18.3\%) use internet resource as electronic information source. Those students who are use E-mail as a electronic information source are U.G. $8(10.9 \%)$ P.G. 2(2.5\%) from JMI.U.G. 1(1.4\%), P.G. 0(0\%) from JNU. There is no response \& U.G., P.G. from D.U. U.G. 12(16.4\%), P.G. 24(30.3\%) from JMI, The UG 8(11.9\%), P.G. 24(29.2\%) from JNU and from D.U., U.G. 29(38.1\%), P.G. 36(41.3\%) are use EJournals as electronic information source. U.G. 7(9.5\%), P.G. 6(7.5\%) from JMI. The UG 6(8.9\%), P.G. 13(15.8\%) from JNU and from D.U., U.G. 3(3.9\%), P.G. 28(32.1\%) use online data as electronic information source. Those student who are use E-books as electronic information source are U.G. 37(50\%) P.G. 28(35.4\%) from JMI.The U.G. 39(58.2\%). P.G. $30(36.5 \%)$ from JNU and U.G. 35(46\%) P.G. 24(27.5\%) from D.U.From the above table it was concluded that mostly U.G. \& P.G. student from JMI, JNU \& D.U. are use internet source as an electronic information source.

Purpose of using the library resources

\begin{tabular}{|c|c|c|c|c|c|c|c|c|c|c|c|c|c|}
\hline \multirow{2}{*}{$\begin{array}{l}\mathbf{S} . \\
\mathbf{n} \\
\mathbf{0}\end{array}$} & \multirow[b]{2}{*}{ variables } & \multicolumn{4}{|c|}{ (JMI) } & \multicolumn{4}{|c|}{ (JNU) } & \multicolumn{4}{|c|}{ (DU) } \\
\hline & & $\begin{array}{l}\mathbf{U G} \\
\mathbf{N}=7 \\
\mathbf{3}\end{array}$ & $\%$ & $\begin{array}{l}\mathbf{P} \\
\mathrm{G} \\
\mathrm{N}= \\
\mathbf{7 9}\end{array}$ & $\%$ & $\begin{array}{l}\mathrm{U} \\
\mathrm{G} \\
\mathrm{N}= \\
67\end{array}$ & $\%$ & $\begin{array}{l}\text { PG } \\
N=8 \\
2\end{array}$ & $\%$ & $\begin{array}{l}\mathbf{U G} \\
\mathbf{N}=7 \\
6\end{array}$ & $\%$ & $\begin{array}{l}\text { PG } \\
N=8 \\
7\end{array}$ & $\%$ \\
\hline $\bar{A}$ & $\begin{array}{l}\text { Borrow } \\
\text { Book }\end{array}$ & 59 & $\begin{array}{l}80 . \\
8\end{array}$ & 61 & $\begin{array}{l}77 . \\
2\end{array}$ & 55 & 82 & 48 & $\begin{array}{l}58 . \\
5\end{array}$ & 62 & $\begin{array}{l}81 . \\
5\end{array}$ & 41 & $\begin{array}{l}47 . \\
1\end{array}$ \\
\hline B & $\begin{array}{l}\text { Consult } \\
\text { Periodica } \\
1\end{array}$ & 7 & 9.5 & 21 & $\begin{array}{l}26 . \\
5\end{array}$ & 0 & 0 & 2 & 2.4 & 7 & 9.2 & 36 & $\begin{array}{l}41 . \\
3\end{array}$ \\
\hline
\end{tabular}




\begin{tabular}{|c|c|c|c|c|c|c|c|c|c|c|c|c|c|}
\hline $\mathrm{C}$ & $\begin{array}{l}\text { Consult } \\
\text { Ref. } \\
\text { Source }\end{array}$ & 0 & 0 & 0 & 0 & 0 & 0 & 0 & 0 & 0 & 0 & 0 & 0 \\
\hline $\mathrm{D}$ & $\begin{array}{l}\text { Thesis/ } \\
\text { Diss. }\end{array}$ & 9 & $\begin{array}{l}12 . \\
3\end{array}$ & 11 & $\begin{array}{l}13 . \\
9\end{array}$ & 2 & 2.9 & 19 & $\begin{array}{l}23 . \\
1\end{array}$ & 6 & 7.8 & 29 & $\begin{array}{l}33 . \\
3\end{array}$ \\
\hline $\mathrm{E}$ & Report & 0 & 0 & 2 & 2.5 & 0 & 0 & 0 & 0 & 0 & 0 & 5 & 5.7 \\
\hline $\mathrm{F}$ & $\begin{array}{l}\text { Browse } \\
\text { Internet }\end{array}$ & 62 & $\begin{array}{l}84 . \\
9\end{array}$ & 57 & $\begin{array}{l}72 . \\
1\end{array}$ & 47 & $\begin{array}{l}70 . \\
1\end{array}$ & 33 & $\begin{array}{l}40 . \\
2\end{array}$ & 27 & $\begin{array}{l}35 . \\
5\end{array}$ & 42 & $\begin{array}{l}48 . \\
2\end{array}$ \\
\hline$G$ & CD-ROM & 2 & 2.7 & 7 & 8.8 & 0 & 0 & 2 & 2.4 & 6 & 7.8 & 3 & 3.4 \\
\hline $\mathrm{H}$ & $\begin{array}{l}\text { Online } \\
\text { Data }\end{array}$ & 1 & 1.3 & 9 & $\begin{array}{l}11 . \\
3\end{array}$ & 0 & 0 & 0 & 0 & 2 & 2.6 & 7 & 8 \\
\hline I & $\begin{array}{l}\text { News } \\
\text { Paper }\end{array}$ & 47 & $\begin{array}{l}64 . \\
3 \\
\end{array}$ & 27 & $\begin{array}{l}34 . \\
1\end{array}$ & 39 & $\begin{array}{l}58 . \\
2\end{array}$ & 18 & $\begin{array}{l}21 . \\
9\end{array}$ & 23 & $\begin{array}{l}30 . \\
2 \\
\end{array}$ & 17 & $\begin{array}{l}19 . \\
5\end{array}$ \\
\hline
\end{tabular}

Table-4.2 shows that, the purpose of using library resources. It indicated that UG $59(80.8 \%)$ and PG 61 (77.2\%) from JMI books. The UG 55 (82\%) and PG 48 (58.5\%) from JNU and the UG 62 $(81.5 \%)$ and PG $41(47.1 \%)$ from DU using library resources for borrowing books.

The students who are using library resources for consult periodical and the UG 7 (9.5\%) and PG $21(26.5 \%)$ from JMI. The student's i.e.no response UG and PG 2(2.4\%) from JNU and the UG $7(9.2 \%)$ and PG 36 (41.3\%) from DU. No body using consult reference source for library those who are using library resources for consult thesis and dissertation are UG 9 (12.3\%) and PG 11(13.9\%) from JMI. The UG 2(2.9\%) CD PG 19 (23.1\%) from JNU and the UG 6(7.8\%) and PG 29 (33.3\%) from DU. No response UG and PG 2 (2.5\%) from JMI and no response UG and PG from JNU. And no response UG using CD PG 5(5.7\%) from using library resources for reported conference proceeding. The students using library resources for browsing Internet are UG 62 (84.9\%) and PG 57 (72.1\%) from JMI, the UG 47 (70.1\%) and PG 33 (40.2\%) from JNU and the UG 27(35.5\%) and PG $42(48.2 \%)$ from DU.

The UG 2(2.7\%) and PG 7 (8.8\%) from JMI, no response of UG and PG 2 (2.4\%) from JNU. The UG $6(7.8 \%)$ and PG 3(3.4\%) from DU are using library resources for CD-Rom. The students who are using online database are UG 1 (1.3\%) and PG 9 (11.3\%) from JMI. There is no response of UG and PG from JNU and UG 2 (2.6\%) and PG 7(8\%) from DU. Those who are using library resources for reading newspaper are UG 47 (64.3\%) and PG 27 (34.1\%) from JMI. The UG 39 (58.2\%) and PG 18(21.9\%) from JNU and the UG 23 (3025) and PG 17 (19.5\%) from DU. From the above the table it is conducted that mostly the UG and PG from JMI, JNU and DU using library resources for borrowing books.

\section{FINDINGS}

- UG 59 (80.8\%) and PG $61(77.2 \%)$ from JMI books. The UG 55 (82\%) and PG 48 $(58.5 \%)$ from JNU and the UG $62(81.5 \%)$ and PG 41 (47.1\%) from DU using library resources for borrowing books.

- UG 37 (50\%), PG 28 (35.4\%) student of JMI, UG 39 (58.2\%), PG 30 (36.5\%) student of JNU and UG 35 (46\%), PG 24(27.5\%) student of DU are used books as use of electronic information source. 
- It was concluded that mostly the UG and PG students from JMI, JNU, and DU are aware about the internet responses.

- UG 33 (45.2\%), PG 39 (49.3\%) students from JMI. UG 45 (67.1\%), PG 36 (43.9\%) from JNU and from DU, UG26 (34.2\%), PG 29 (33.3\%) are facing problem while using Eresources due to lack of training.

- It was found that UG \& PG students of JMI, JNU and DU are $100 \%$ aware about the book service available in the library.

\section{CONCLUSION}

The study has shown that user education is constrained by various factors, so affecting the image of library, library usage frequency, and library use instruction patterns. The responses illustrate that existing practices of user education programmes are organized on an informal basis in most universities; some provide together formal and informal schemes. One reason for the domination of informal programmes is the lack of policy, lack of provision of resources for a formal programme and lack of cooperation between the university authorities and library management. The survey suggests that, despite many difficulties, there remains some deal of activity in this field; most students in universities are exposed to library orientation, but there is less provision of basic bibliographic instruction and advanced bibliographic instruction. Lack of awareness of the importance of such programmes and resource constraints appears to be an important dilemma in initiating and developing an effective programme. It has forced library staff into partial retreat as they have already been preoccupied with their other basic services and responsibilities.

One restriction to the success of such programmes in the universities i.e (JAMIA MILLIA ISLAMIA, JAWAHAR LAL NEHRU, and DELHI UNIVERSITY) is the absence of interaction between the library staff and the faculty. It was found that there is little consultation with faculty in the planning (setting the objectives and contents, teaching methods and techniques and evaluations) and implementation. The experts told that there is some sort of common suspicion about the intent and targets of programmes among the faculty. The psychological problems are reported in the library staff in terms of the non-appreciation of their efforts and their inequality of status.

The reasons for not establishing user education as an imperative element of higher education cannot solely be described in terms of resource problems. It emerges from the responses that most librarians are not equipped with required knowledge and training to teach users effectively. It was also revealed that a majority do not have adequate subject expertise and that library science curricula do not insist on the information and educational objectives of libraries and do not consider library user education as an important element of library practice. Some resistance has been reported from the faculty who think that library staff members lack teaching experience and the necessary subject knowledge. Library staff members have to go a long way towards building the sense of confidence in which the faculty trust the capabilities of library staff and motivate their students to attend the user education course. 


\section{RECOMMENDED}

1) Systematic study of the effectiveness of Orientation Programs should be regular duty of library staff and suitable methods should be developed from time to time in consultation with teaching staff.

2) A single run of tape/slide lecture and or a group visit to the library is not entirely effective. It has to be followed up by other methods, such as library guides, user assistance when needed, etc.

3) All university libraries should try to utilize the forums of specific and technical meetings, conventions, symposia etc. to orient the potential users by way of presenting the latest techniques for organization of knowledge in specialized areas and arranging lectures etc.

4) The university libraries must conduct surveys and other techniques in order to assess their users' needs assessment and information seeking behavior on regular basis.

5) Effectiveness of the library orientation can be conducted by evaluating a survey for the students, research scholars and faculties at the end of every academic year.

6) User interaction need to be conducted frequently, to the students \& faculties and update them with the new additions and new innovative practices implemented in the library.

7) Library orientation should be an integral part of the fresher's day/ college orientation or can be done separately but should be included in the timetable at the commencement of the academic year.

\section{REFERENCE}

[1] Abdunaby, J.S. and Alaani, W.T. 2000. Information educational we need for university students to participate in social development process. Ala'rabya 3000, No.1: $79-92$.

[2] Bhatti, Rubina, (2007), User Education Programme in the John Rylands University Library of Manchester: A Case Study, Pakistan Journal of Library \& Information Science, vol. 2007, n. 8, pp. 49-62.

[3] Julien, H. 2000. Library Orientation Program in Canadian academic libraries: longitudinal trends and international comparisons. College \& Research Libraries, Vol.61, no.6: 510-551.

[4] Mark, A.E. and Boruff, J. 2003. Information literacy and student engagement: what the national survey of students engagement reveals about your campus. College \& Research Libraries. Vol.64, no.6: 480 - 492.

[5] Mohammad, A.H.A. 2003. Role of the libraries in environmental information literacy: Survey study for some public libraries in Cairo and Jeeza provinces. New Trends in Libraries and Information. Vol.11, no.20: $289-296$.

[6] Naser, W.G. 2004. The supporting role of the educational bibliographic program in Users' Ratings on the Improved Library Orientation Programme at Zarqa Private University Page | 71 academic libraries for the scientific research. CybrariansJournal . No.3

[7] Raman Nair, R. (1995), User orientation programmes in College Libraries, Indian Journal of Information, Library and Society, vol. 8, n. 1-2, pp. 49-58.

[8] Sewa, Singh, (1992), User education in university libraries : what, why and how?, , EssEss Publications, New Delhi. 